\title{
MORFOLOGI, KLASIFIKASI, DAN SEBARAN CUMI-CUMI FAMILI LOLINGINIDAE
}

\author{
Oleh \\ Diah Anggraini Wulandari ${ }^{1)}$
}

\begin{abstract}
MORPHOLOGY, CLASIFICATION, AND DISTRIBUTION OF SQUID FAMILY

LOLINGINIDAE. Squids are one of Indonesian export commodities that is produced in frozen, salted, dried or canned, however the information about biology,ecology, habitat and distribution of squid are little known. Squid have ten tentacles equipped with suction, and generates ink to defend against their enemies. Squids are demersal or semi-pelagic animal that lives in the waters column up to a depth of $400 \mathrm{~m}$ with diurnal movements. Squids reproduce sexually and by deocious. Squids with family Lolinginidae (genus Lolious) are distributed across the Indonesian waters with temperatures of 8 to $32^{\circ} \mathrm{C}$ and salinity of 8.5 to $30 \mathrm{ppm}$. Familly Lolinginidae is grouped into several genera included Afrololigo, Allotheuthis, Dorytheuthis, Heterololigo, Loliolus, Lollinguncula, Pickfordiateuthis, Sepioteuthis, dan Urotheuthis
\end{abstract}

\section{PENDAHULUAN}

Perairan Indonesia memiliki potensi sumberdaya perairan laut yang cukup besar, diantaranya adalah ikan pelagis, karang, udang, lobster, dan cumicumi. Kontribusi hasil tangkapan cumicumi sangatlah sedikit dibandingkan dengan produksi total perikanan Indonesia yaitu hanya $0,8 \%$ (Prima \& Puspasari, 2011). Produksi cumi-cumi pada tahun 2010 tercatat mencapai $34.925 .401 \mathrm{~kg}$, kemudian menunjukkan peningkatan yang cukup tajam pada tahun 2011 sebesar $48.803 .318 \mathrm{~kg}$, dan tahun 2012 sebesar $58.145 .503 \mathrm{~kg}$.

Produksi cumi-cumi di Indonesia diperkirakan mencapai 58,25 ribu ton per tahun (KKP, 2013). Peningkatan

\footnotetext{
1) Pusat Penelitian Oseanografi-LIPI
}

ekspor ini ternyata masih jauh lebih kecil dari kebutuhan pasar dunia sebagai contoh negara Amerika pada tahun 2010 membutuhkan 640 ribu ton, Jepang 580 ribu ton, sedangkan produksi dalam negeri hanya mampu menghasilkan 58,25 ribu ton (KKP, 2013). Tingginya permintaan pasar terhadap cumi-cumi sebagai komoditas ekspor Indonesia menjadikan cumi-cumi sebagai salah satu hasil tangkapan utama selain ikan, dan lobster, namun disisi lain, pengetahuan masyarakat mengenai kelompok cumicumi masih sangat terbatas sehingga masyarakat perlu mengenal terkait morfologi, jenis dan sebaran cumi-cumi khusus nya di Indonesia.

Cumi-cumi merupakan salah satu jenis Filum Molusca, Kelas Cephalopoda 
yang tidak bertulang belakang. Molusca merupakan hewan bertubuh lunak, sebagian anggotanya dilindungi dengan cangkang dari zat kapur dan sebagian lainnya tanpa cangkang (Kusnadi et al., 2008). Chepalopoda berasal dari kata cephal: kepala, poda: kaki, yang berarti memiliki kaki (tentakel) di bagian kepala. Beberapa jenis cephalopoda memiliki nilai komersial dan merupakan salah satu sumberdaya hayati penting dalam sektor perikanan laut misalnya cumi-cumi (squid), sotong (cuttlefish), dan gurita (octopus) (Roper et al., 2006).

Perbedaan mendasar antara cumi-cumi (squid), sotong (cuttlefish) dan gurita (octopus) yaitu cumicumi memiliki tubuh lebih panjang dibandingkan dengan tubuh sotong maupun gurita, dengan sirip berbentuk belah ketupat, sedangkan sotong (Sepia $s p)$ memiliki tubuh berbentuk bulat agak pendek dengan panjang 30-35 cm, sirip melingkari seluruh badan dan bagian belakang tubuh bulat. Warna sotong bervariasi tetapi umumnya coklat atau kuning kecokelatan dengan garis-garis di punggung (Hartati, 2004). Gurita umumnya berbentuk agak bulat dan pendek, tidak memiliki sirip. Bagian utama dari tubuh gurita menyerupai gelembung dengan lengan berjumlah delapan dan dilengkapi dengan selaput renang (Budiyanto \& Sugiarto, 1997). Perbedaan morfologi cumi-cumi, sotong dan gurita dapat dilihat pada Gambar 1 .
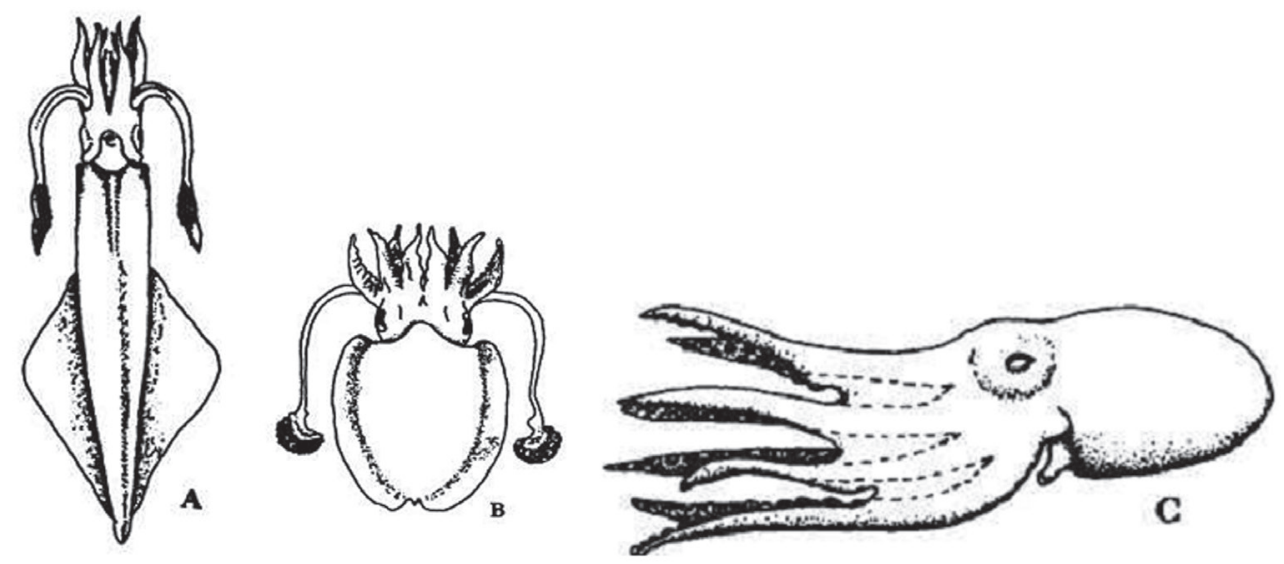

Gambar 1. Perbedaan bentuk morfologi a) cumi-cumi (squid), b) sotong (cuttlefish), c) Gurita (octopus) (Budiyanto \& Sugiarto, 1997).

\section{MORFOLOGI DAN ANATOMI CUMI-CUMI FAMILI LOLINGINIDAE}

Cumi-cumi merupakan salah satu jenis chepalopoda bertubuh lunak, dan memiliki cangkang yang terbuat dari sel kapur. Secara umum, biologi cumi-cumi Famili Lolinginidae tidak jauh berbeda dengan jenis chepalopoda lainya. Cumicumi memiliki kepala dan kaki yang dapat dibedakan dengan jelas. Organ 
mata terdapat di kepala dengan ukuran yang besar, tentakelnya dilengkapi dengan alat penghisap yang berfungsi sebagai kemudi ketika berenang. Selain itu juga tentakel digunakan untuk mempertahankan diri dan menangkap mangsa (Kusnadi et al., 2008). Sistem pergerakannya menggunakan sifon yang mengatur sirkulasi air untuk dilewatkan ke insang. Sifon menyeprotkan air keluar dengan cepat sehingga memberikan daya dorong, cumi-cumi bergerak sesuai arah yang diinginkan dengan cara mengatur posisi sifon. Sistem ini disebut dengan sistem jet prepultion (Nontji, 2002). Cumi-cumi bersifat dioecious dan melakukan reproduksi dengan kopulasi. Pada individu jantan terdapat modifikasi lengan yang disebut hectocotylus, yang berfungsi untuk menyuntikkan sperma ke dalam mantel individu betina (Rocha et al., 2001).

\section{Cumi-cumi memiliki ciri-} ciri mantel memanjang, ramping, berujung tumpul, sirip berbentuk belah ketupat, panjang sirip dan panjang mantel bervariasi. Panjang mantel maksimum $400 \mathrm{~mm}$, namun secara umum panjang mantel cumi-cumi yaitu $200 \mathrm{~mm}$ (Chodrijah \& Budiarti, 2011). Cumi-cumi menangkap mangsanya menggunakan tentakel, selain itu hewan ini dapat mengelabui musuhnya dengan menyemprotkan cairan tinta berwarna gelap atau merubah warna kulitnya (Roper et al., 2006). Cumi-cumi merupakan penghuni demersal atau semipelagik pada daerah pantai dan paparan benua sampai kedalaman $700 \mathrm{~m}$. Pergerakan cumicumi dilakukan secara diurnal, yaitu pada siang hari akan berkelompok dekat dasar perairan dan akan menyebar pada kolom perairan ketika malam hari. Cumi-cumi tertarik pada cahaya (fototaksis positif), oleh karena itu sering ditangkap dengan menggunakan bantuan cahaya (Jereb \& Roper, 2010).

Cumi-cumi Lolinginidae memiliki lima pasang lengan, dengan satu pasang lengan yang lebih panjang dibandingkan lainnya dan disebut tentakel. Lengan paling dorsal atau paling atas disebut dengan lengan I kemudian diikuti dengan lengan II yang terletak di latero dorsal, lengan III yang letaknya latero-ventral dan lengan yang terletak di bagian paling ventral. Setiap lengan memiliki alat peghisap (sucker) dengan diameter kurang dari 2 mm (Roper, 1984). Setiap alat penghisap memiliki 17 hingga 28 gigi tajam berbentuk segitiga, dengan lengan kiri IV jantan memiliki hectocotylus yang berfungsi untuk memasukan spermatofora dalam tubuh betina. Tentakel pada cumi-cumi berfungsi untuk menangkap mangsa terletak diantara lengan III dan IV, panjang dan kuat. Pada bagian ujung tentakel melebar dan menebal, terdapat duri-duri isap yang disebut dengan gada (tentacular club). Gada dapat dibedakan menjadi tiga bagian yaitu dactylus yang terletak di bagian ujung yang meruncing, manus yang terletak di bagian tengah yang melebar, dan carpus yang terletak pada bagian pangkal (Nateewathana, 1992). Morfologi dan bagian-bagian tubuh cumi-cumi dapat dilihat pada Gambar 2. 

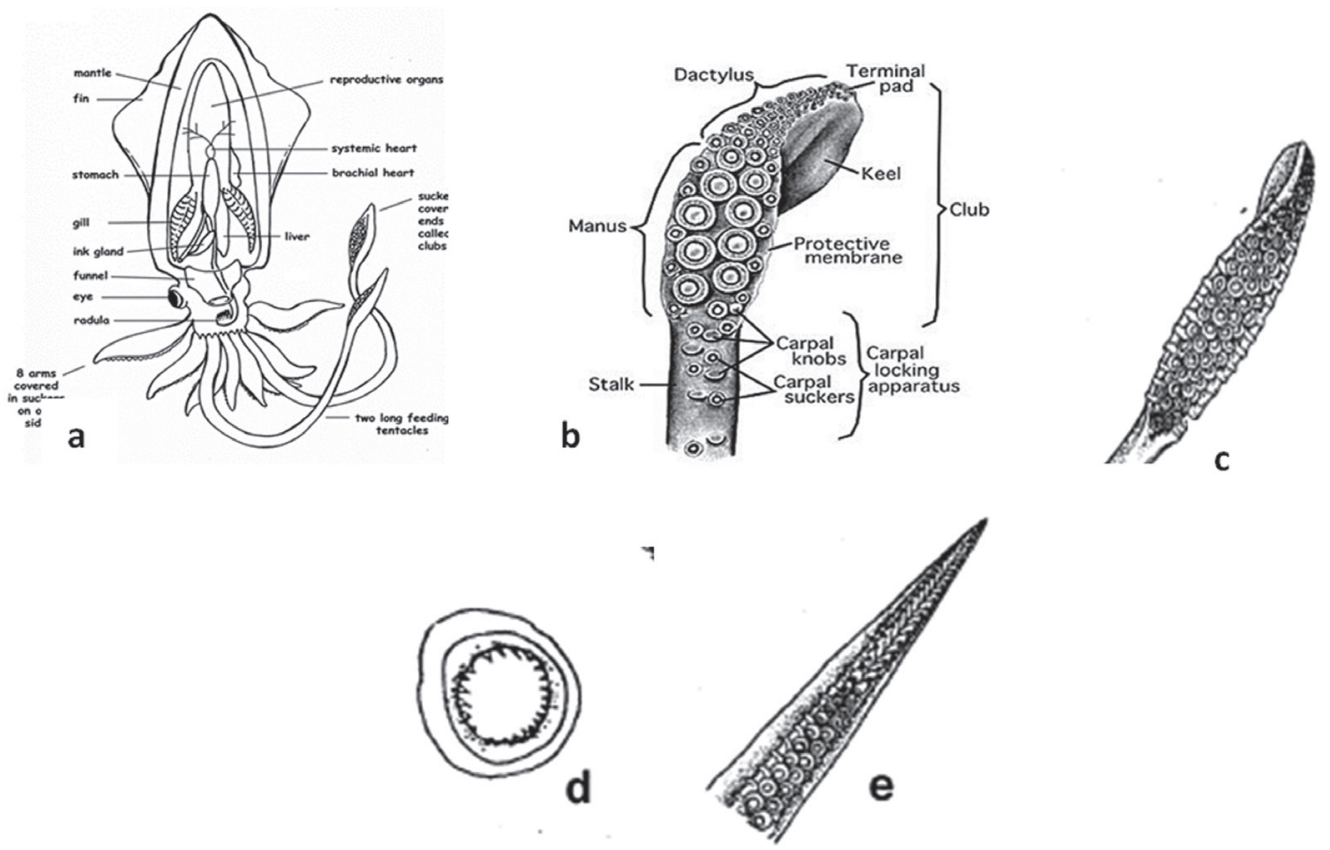

Gambar 2. Morfologi dan bagian-bagian lengan. a) morfologi cumi-cumi, b) dan c) gada (tentacular club), e) hectocotylus, f) alat penghisap pada lengan 3. (sumber: a, www.exploringnature.org, b dan c, Roper et al., 2009, d dan e, Nateewathana 1992).

\section{KLASIFIKASI JENIS CUMI-CUMI FAMILI LOLINGINIDAE DAN SEBARANNYA}

Kelas Lolinginidae memiliki ciriciri kulit transparan, lensa mata tertutup oleh aquiferouspore. Sirip pada cumicumi Kelas Lolinginidae menempel pada daerah lateral mantel dengan dua tentakel penghisap. Cumi-cumi betina memiliki saluran telur tunggal dengan kelenjar nidamental yang melekat pada substrat. Famili Lolinginidae berukuran kecil hingga besar, dengan ukuran panjang mantel maksimum $937 \mathrm{~mm}$, berwarna coklat kemerahan, bagian punggung gelap, dan bervariasi tergantung pada tingkah lakunya (Vecchione et al., 2005). Lolinginidae dapat ditemukan di perairan demersal, dekat dengan pantai, beberapa spesies terdapat di perairan yang dangkal seperti teluk, muara, ekosistem lamun maupun terumbu karang hingga kedalaman lebih dari $700 \mathrm{~m}$ (Jereb \& Roper, 2010). Klasifikasi taksonomi dari jenis cumi-cumi Lolinginidae dapat dilihat pada Tabel 1. 
Tabel 1. Klasifikasi taksonomi dari jenis cumi-cumi Lolinginidae (Jereb \& Roper, 2010).

\begin{tabular}{|c|c|c|}
\hline Genus & Sub Genus & Species \\
\hline Loligo & & forbesii, reynaudii, vulgaris \\
\hline Afrololigo & & mercatoris \\
\hline Allotheuthis & & africana, media, subulata \\
\hline \multirow[t]{2}{*}{ Doryteuthis } & Doryteuthis & plei, roperi \\
\hline & Amerigo & $\begin{array}{l}\text { gahi, ocula, opalescens, pealeii, surinamensis } \\
\text { sanpaulensis }\end{array}$ \\
\hline Heterololigo & & bleekeri \\
\hline \multirow[t]{2}{*}{ Loliolus } & Loliolus & affinis, hardwickei \\
\hline & Nipponololigo & beka, japonica, sumatrenensis, uyii \\
\hline \multirow[t]{2}{*}{ Lolliguncula } & Loliguncula & argus, brevis, panamensis \\
\hline & Loliolopsis & Diomedeae \\
\hline Pickfordiateuthis & & bayeri, pulchella, vossi \\
\hline Sepioteuthis & & australis, lessoniana, sepioidea \\
\hline \multirow[t]{3}{*}{ Uroteuthis } & Uroteuthis & bartschi \\
\hline & Aestuariolus & Moctiluca \\
\hline & Photololigo & $\begin{array}{l}\text { abulati, arabica, bengalensis, chinensis, duvaucelli, } \\
\text { edulis, machelae, robsoni, sibogae, singhalensis, } \\
\text { vossi, Pickfordi, reesi }\end{array}$ \\
\hline
\end{tabular}

Genus Loligo Lamarck, 1798

Genus Loligo memiliki ciri-ciri tentakel lebar, berukuran kecil hingga besar dengan panjang mantel maksimum $937 \mathrm{~mm}$. Genus Loligo ditemukan di Samudera Atlantik Timur dan Laut Mediterania. Jenis spesies dari genus Loligo antara lain Loligo forbesii, Loligo reynaudii, Loligo vulgaris.

\section{a. Loligo vulgaris}

Loligo vulgaris memiliki ciriciri mantel panjang, agak ramping, sirip berbentuk belah ketupat, posterior sedikit cekung. Cincin penghisap terdiri dari 30 gigi yang tidak beraturan, panjang mantel maksimum pada $L$. vulgaris jantan yaitu $640 \mathrm{~mm}$ sedangkan pada betina yaitu $485 \mathrm{~mm}$. Berat badan maksimum $L$. vulgaris jantan 2,3 $\mathrm{kg}$ dan 1,23 $\mathrm{kg}$ pada $L$. vulgaris betina. Daerah distribusi $L$. vulgaris yaitu Samudera Atlantik Timur dari $55^{\circ} \mathrm{LU}-0^{\circ} \mathrm{LS}$ di sekitar Kepulauan Inggris, Laut Utara, Skagerrak, Kattegat dan Laut Baltik Barat, lepas pantai Barat daya Afrika, Perairan Mediterania. Loligo vulgaris dapat ditemukan di wilayah perairan beriklim sedang di kedalaman $200-500 \mathrm{~m}$, suhu $12,5^{\circ}$ hingga $20{ }^{\circ} \mathrm{C}$, dengan kisaran salinitas 30-38 psu. Loligo vulgaris umumnya memiliki habitat pelagis, namun selama musim bertelur berada pada perairan demersal dan melakukan migrasi ke utara dari bulan Mei hingga Juli (Vecchione et al., 2008a). Pemijahan dilakukan sepanjang tahun dengan dua puncak musim, dan banyak ditemukan di Laut Utara dan di Laut Yunani. Potensi fekunditas lebih 
dari 70.000 telur. Tingkat fekunditas cenderung bervariasi bergantung pada ukuran $L$. vulgaris betina dan spermatophore L. vulgaris jantan. Jumlah maksimum spermatopore lebih dari 1000 dengan panjang spermatophore berkisar 7,5 hingga $18 \mathrm{~mm}$ (Jereb \& Roper, 2010). Morfologi Loligo vulgaris dapat dilihat pada Gambar 3. a

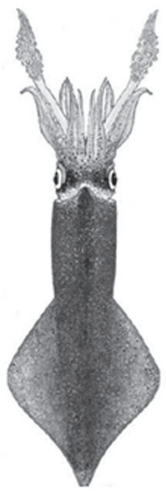

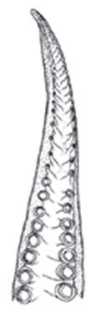

b

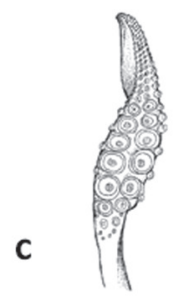

Gambar 3. Morfologi Loligo vulgaris a) penampakan dorsal, b) lengan Hectocotylus, c) tentacular club (Sumber: Jereb \& Roper, 2009).

\section{b. Loligo forbesii (Steenstrup, 1856)}

Loligo forbesii memiliki ciriciri mantel panjang, agak ramping, panjang sirip tiga perempat dari mantel, perbatasan posterior sedikit cekung. Cincin penghisap pada tentacular club terdiri dari 13-18 gigi tajam dan berbentuk kerucut. Ukuran panjang
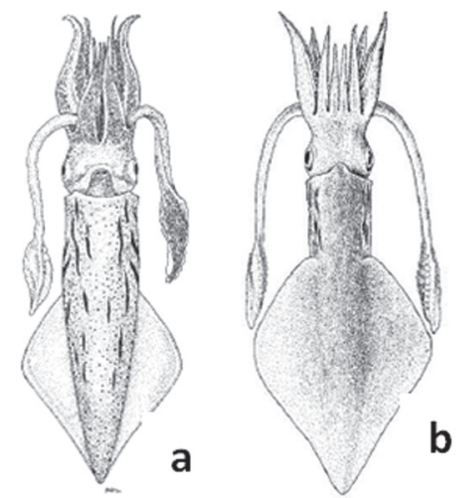

mantel maksimum L. forbesii yaitu 937 $\mathrm{mm}$ dengan berat $8,3 \mathrm{~kg}$ pada $L$. forbesii jantan dan $462 \mathrm{~mm}$ dengan berat $2,2 \mathrm{~kg}$ pada $L$. forbesii betina. Umumnya ukuran panjang mantel cumi-cumi jenis ini yaitu 200-300 mm (Hastie et al., 2009). Morfologi L. forbesii dapat dilihat pada Gambar 4.

Gambar 4. Morfologi Loligo forbesii a) penampakan ventral, b) dorsal, c) lengan hectocotylus, d) tentacular club (Jereb \& Roper, 2010). 
Distribusi geografis L. forbesii yaitu Atlantik utara bagian timur 20 ${ }^{\circ} \mathrm{LU}$ - $60{ }^{\circ} \mathrm{LU}$, berkisar dari Kepulauan Faeroe, sepanjang pantai Eropa barat, barat ke Kepulauan Azore dan selatan ke Kepulauan Canary, di sepanjang Afrika barat. $L$ forbesii merupakan spesies yang hidup di perairan subtropis dengan suhu kurang dari $8,5^{\circ} \mathrm{C}$. Loligo forbesii terdapat di perairan dengan kedalaman 50-700 m, dan ditemukan paling banyak di kedalaman 100 hingga $200 \mathrm{~m}$.

\section{c. Loligo reynaudii Orbigny}

Loligo reynaudii Orbigny memiliki nama lain Loligo vulgaris reynaudii. Loligo reynaudii memiliki ciri-ciri mantel memanjang dan kecil, panjang sirip lebih dari panjang mantel. Tentakel terdiri lebih dari 36 baris cincin penghisap (sucker) masing masing cincin penghisap terdiri dari 16 hingga 20 gigi tajam. Ukuran panjang mantel maksimum 400 $\mathrm{mm}$ dengan berat lebih dari $1 \mathrm{~kg}$. Loligo reynaudii jantan biasanya memiliki panjang mantel 90-250 mm sedangkan betina memiliki panjang mantel 100-180 $\mathrm{mm}$. Pemijahan $L$. reynaudii terjadi di perairan pantai dengan kedalaman $<60$ $m$ pada musim semi hingga musim panas (September-Februari) dengan suhu 9-12 ${ }^{\circ} \mathrm{C}$. Potensi fekunditas L. reynaudii yaitu sekitar 17.000 telur dengan lebar 2,0 mm dan panjang 2,8 $\mathrm{mm}$. Telur membutuhkan sekitar 25 hari untuk menetas pada suhu $14{ }^{\circ} \mathrm{C}$ dan 16 hari pada suhu $21-22{ }^{\circ} \mathrm{C}$ (Vecchione et al., 2008a). Morfologi $L$. reynaudii dapat dilihat pada Gambar 5.

Distribusi geografis L. reynaudii yaitu di Perairan Afrika Selatan, timur Atlantik Selatan dan barat daya Samudera Hindia, tersebar dari Namibia hingga ke Cape Agulhas. Loligo reynaudii terdapat di sepanjang landas kontinen hingga kedalaman $200 \mathrm{~m}$. Loligo reynaudii bermigrasi ke utara di Afrika barat daya untuk tumbuh dan mencari makan, kemudian kembali ke perairan pantai timur untuk bertelur (Lipinski et al., 1990).
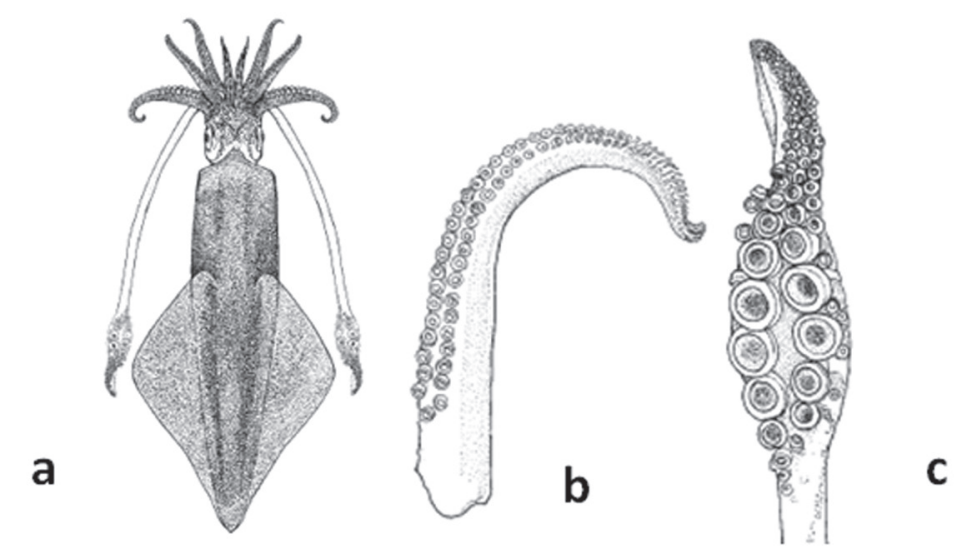

Gambar 5. Karakteristik dan morfologi L. reynaudii a) penampakan dorsal, b) lengan hectocotylus, c) tentacular club (Jereb \& Roper, 2010). 
Genus Afrololigo

Afrololigo mercatoris (Adam, 1941)

Afrololigo mercatoris memiliki ciri-ciri mantel lebar, berbentuk bulat secara posterior, sirip bulat dan pendek, lebar kedua sirip sekitar 55 hingga $65 \%$ dari panjang mantel dengan pinggiran posterior cembung, kepala pendek, tentakel kecil, cincin penghisap terdiri dari 15 hingga 25 gigi tajam, besar dan runcing dibagian distal. Lengan hectocotylus pada bagian ventral terdiri dari 6 sampai 12 pasang cincin penghisap (Sucker) (Vacchione et al., 2008a).
Morfologi Afrololigo mercatoris dapat dilihat pada Gambar 6 .

Afrololigo mercatoris betina memiliki panjang mantel maksimum 50 mm pada A. mercatoris betina dan 35 mm pada A. mercatoris jantan. Daerah persebaran A. Mercatoris yaitu Samudera Atlantik bagian tengah timur di daerah sekitar pantai barat Afrika dari Rio de Oro (Mauritania) ke Lüderitz Bay. Habitat A. mercatoris terdapat pada kedalaman kurang dari $50 \mathrm{~m}$ di daerah pasir dan berlumpur.

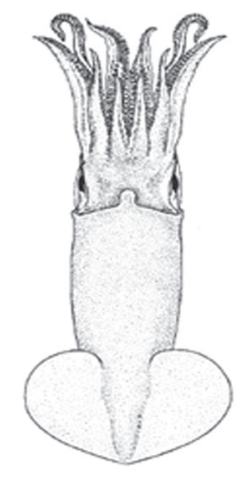

a

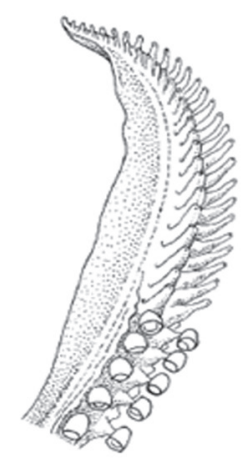

b

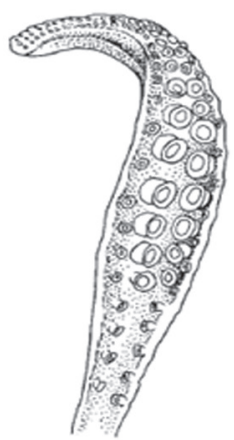

C

Gambar 6. Morfologi Afrololigo mercatoris a) Penampakan dorsal, b) Lengan hectocotylus, c) Tentacular club (Jereb \& Roper, 2010).

\section{Genus Alloteuthis}

\section{a. Alloteuthis media (Linnaeus, 1758)}

Alloteuthis media memiliki ciriciri kecil, runcing, berukuran kurang dari $10 \mathrm{~mm}$, sirip berbentuk hati, sudut lateral membulat, tentakel panjang dan kuat. Daerah distribusi A. media yaitu di Perairan Laut Atlantik utara bagian timur dan Laut Tengah sekitar $20^{\circ} \mathrm{LU}$ sampai $60^{\circ} \mathrm{LU}$ di Atlantik bagian timur.
Spesies ini tersebar luas di seluruh Laut Tengah, termasuk Laut Marmara. Habitat A. media terdapat di daerah berpasir dan berlumpur, ditemukan di permukaan sampai kedalaman $200 \mathrm{~m}$. Alloteuthis media bermigrasi ke perairan dangkal pada bulan Maret hingga April, dimana pemijahan terjadi di perairan berpasir dan padang lamun (Anderson et al., 2006). Morfologi dan daerah distribusi A. media dilihat pada Gambar 7. 

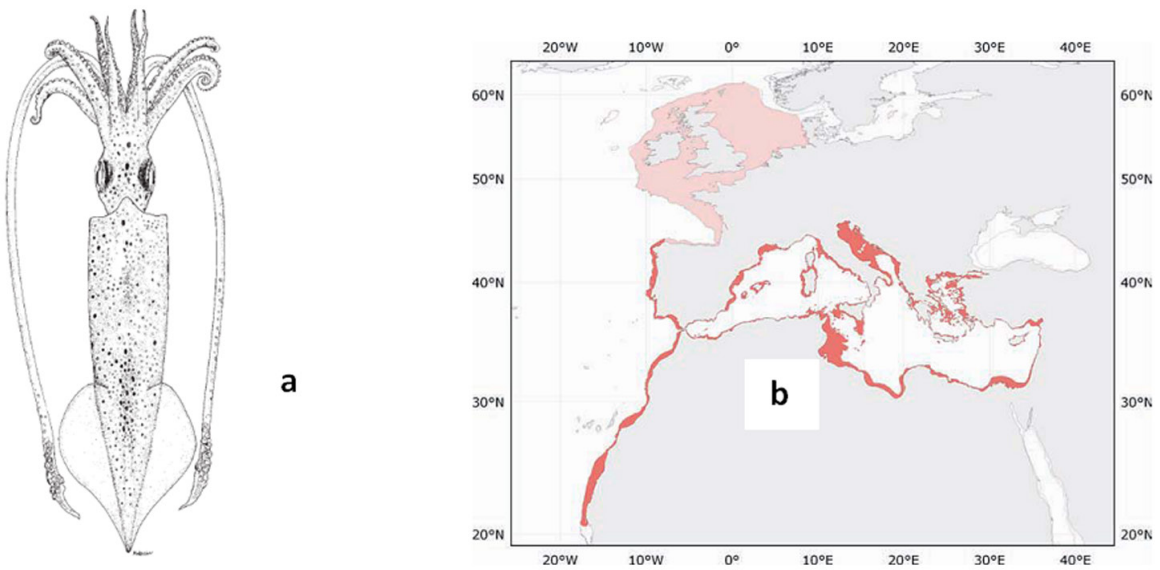

Gambar 7. a) Morfologi dan b) daerah distribusi Alloteuthis media (Jereb \& Roper, 2010).

\section{b. Alloteuthis africana}

Alloteuthis africana memiliki ciriciri mantel panjang dan kecil, bagian ekor memanjang dan meruncing. Sirip berbentuk oval, lengan pendek, tidak memiliki alat penghisap pada lappet buccal, bagian ekor A. africana jantan lebih panjang dibandingkan betina. Cincin penghisap terdiri dari 20-30 gigi tumpul. Alloteuthis africana berukuran sedang dengan panjang mantel maksimum 205 $\mathrm{mm}$ pada cumi-cumi jantan, dan $175 \mathrm{~mm}$ pada cumi-cumi betina (Vecchione et al., 2008b). Daerah distribusi Alloteuthis africana yaitu Atlantik timur dari 20 - 25 ${ }^{\circ}$ LU. Alloteuthis africana ditemukan di lepas pantai Afrika Barat pada kedalaman 20- $00 \mathrm{~m}$ dengan suhu $16-26{ }^{\circ} \mathrm{C}$. Umur A. africana diperkirakan kurang dari satu tahun, dengan usia A. africana jantan rata-rata kurang dari 8 bulan (Anderson et al., 2008). Bentuk morfologi dan daerah distribusi $A$. africana dapat dilihat pada Gambar 8.
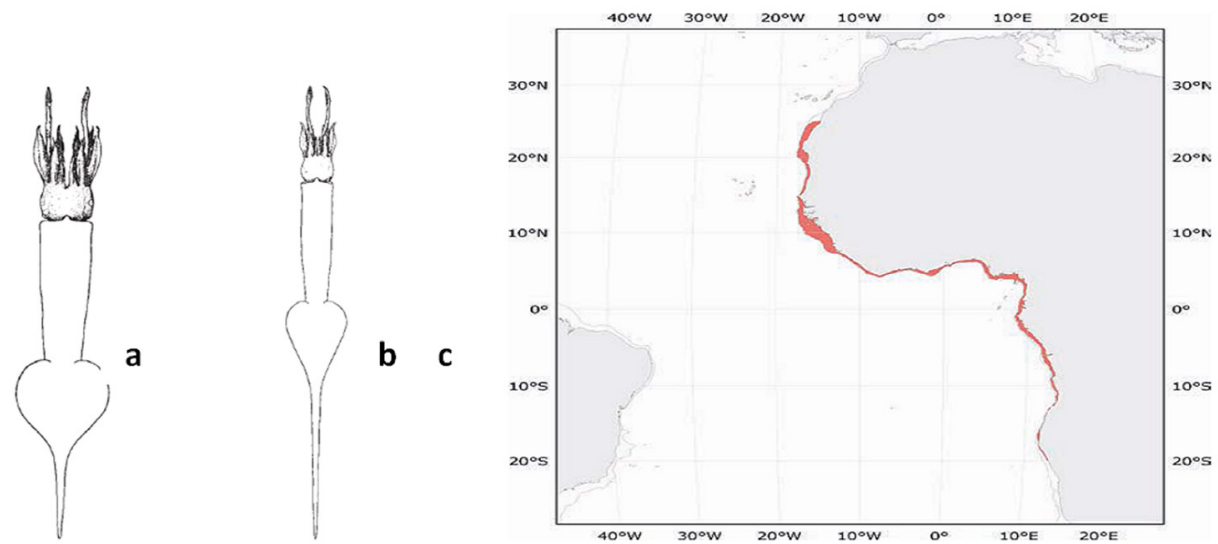

Gambar 8. Morfologi Alloteuthis africana a) jantan, b) betina dan c) daerah distribusi. 


\section{c. Alloteuthis subulata (Lamarck, 1798)}

Alloteuthis subulata memiliki ciri-ciri mantel memanjang, ekor panjang dan runcing, berbentuk belah ketupat dengan posterior cekung, sirip lebih panjang daripada mantel, tidak memiliki alat penghisap (sucker) pada lappet buccal, tentakel pendek, halus, dan kecil. Jenis cumi-cumi ini memiliki ukuran kecil hingga sedang dengan panjang mantel maksimum $184 \mathrm{~mm}$ pada cumicumi jantan, $140 \mathrm{~mm}$ pada cumi-cumi betina. Daerah distribusi $A$. subulata antara lain Samudra Atlantik Timur, dari sekitar $60{ }^{\circ} \mathrm{LU}$ sampai $20^{\circ} \mathrm{S}$, Laut Baltik, Laut Utara dan Laut Celtic, ke pantai barat Irlandia, selatan Sahara, dan Laut Mediterania. Alloteuthis subulata ditemukan di kedalaman 50 hingga 500 m (Jereb \& Roper, 2010).

\section{Genus Doryteuthis}

Subgenus Doryteuthis terdiri dari 5 jenis spesies yaitu Doryteuthis plei, Doryteuthis roperri, Doryteuthis gahi, Doryteuthis ocula, Doryteuthis opalescens, Doryteuthis pealeii. Morfologi kelima spesies tersebut dapat dilihat pada Gambar 9.
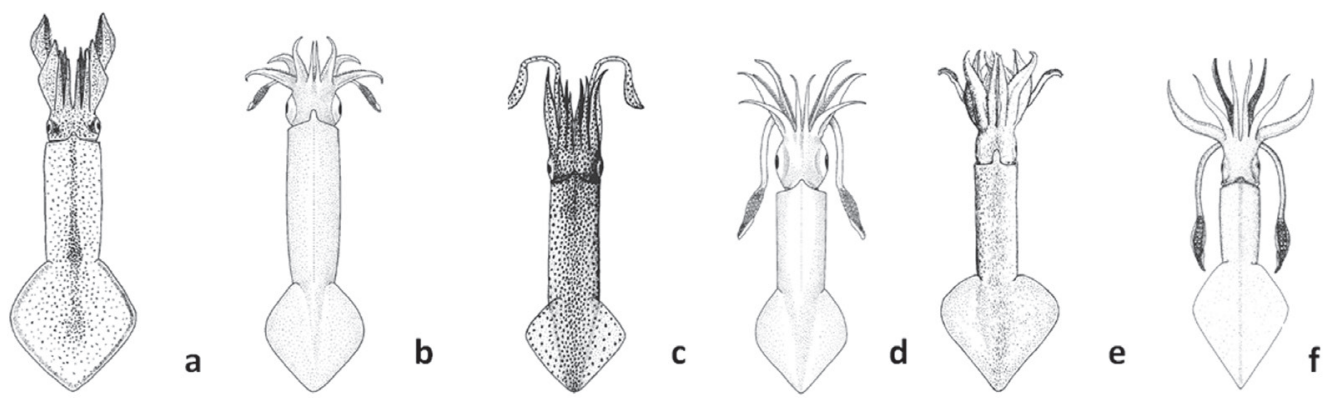

Gambar 9. Morfologi subgenus Doryteuthis a) D. plei, b) D. roperri, c) D. gahi d) D.

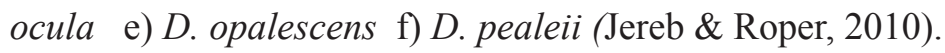

\section{a. Doryteuthis plei}

Doryteuthis plei memiliki ciriciri mantel panjang, ramping, berbentuk silinder, penghisap di bagian dorsal lebih kecil dibandingkan bagian ventral, lappet buccal ventral terdapat cincin penghisap, bagian punggung berwarna coklat kemerahan. D. plei memiliki panjang mantel maksimum $370 \mathrm{~mm}$ pada cumicumi jantan, dan $260 \mathrm{~mm}$ pada cumicumi betina. Daerah distribusi D. plei adalah Samudera Atlantik Barat, di landas kontinen dan Perairan Lerang bagian atas dari Tanjung Hatteras. Cumi-cumi jenis ini banyak ditemukan di permukaan hingga kedalaman $370 \mathrm{~m}$ (Perez et al., 2002).

\section{b. Doryteuthis roperri}

Doryteuthis roperi memiliki ciriciri mantel panjang, ramping, berbentuk silindris, beberapa spesies memiliki sirip berbentuk oval. Tentakel pendek dan kuat, kromatofor berwarna coklat kemerahan di bagian mantel. Doryteuthis roperi memiliki mantel dengan panjang maksimum $72 \mathrm{~mm}$. Daerah distribusi 
spesies ini yaitu di daerah barat Samudera Atlantik disekitar Laut Karibia dan Teluk Meksiko (Jereb \& Roper, 2009).

\section{c. Doryteuthis gahi}

Doryteuthis gahi sering disebut juga Loligo gahi. Doryteuthis gahi memiliki ciri-ciri mantel agak panjang, sirip pendek, tentakel panjang, dan kecil, lengan memanjang terutama di bagian ventral dan lengan ventrolateral, cincin penghisap terdiri dari 6 atau 7 gigi yang lebar dan rata (Arkhipkin et al., 2006). Cumi-cumi jenis ini berukuran sedang, panjang mantel maksimum yaitu $340 \mathrm{~mm}$ pada cumi betina dan $400 \mathrm{~mm}$ pada cumi jantan. Daerah distribusi D. gahi terletak di Samudera Atlantik Timur dari Chili Selatan dan barat daya Atlantik Ocean dari Teluk San Matias hingga Tierra del Feugo. Doryteuthis gahi banyak ditemukan hingga kedalaman 300 - 600 $\mathrm{m}$ (Vega et al., 2002).

\section{d. Doryteuthis ocula}

Doryteuthis ocula memiliki ciriciri mantel lurus kearah posterior, panjang sirip $45-55 \%$ panjang mantel, mata besar, lengan hectocotylus dimodifikasi, tentakel kuat dan lebar. Doryteuthis ocula memiliki panjang mantel maksimum 127 $\mathrm{mm}$. Daerah distribusi spesies ini terletak di Atlantik Barat, Laut Karibia, di sekitar Kuba. Doryteuthis ocula ditemukan di kedalaman 250 hingga $360 \mathrm{~m}$ (Vecchione et al., 2008c).

\section{e. Doryteuthis opalescens}

Doryteuthis opalescens memiliki ciri-ciri mantel ramping, lebar 20-33\% dari panjang mantel, panjang sirip sama dengan lebarnya, kantung tinta berbentuk memanjang, cincin penghisap terdiri dari 9-12 gigi tumpul. Doryteuthis opalescens memiliki ukuran kecil hingga sedang dengan panjang mantel maksimum 190 $\mathrm{mm}$, rata-rata panjang mantel cumi-cumi jenis ini yaitu 140-170 mm. Doryteuthis opalescens endemik di wilayah California Canada, dan Meksiko (Zeidberg et al., 2006).

\section{f. Doryteuthis pealeii}

Doryteuthis pealeii memiliki ciri-ciri mantel panjang, agak ramping, berbentuk silindris, ujung posterior tajam. Gladius panjang, agak lebar, mata besar, warna coklat kemerahan, bagian punggung lebih gelap. Cumi-cumi jenis ini berukuran sedang hingga besar, panjang mantel maksimum $465 \mathrm{~mm}$ pada cumi-cumi jantan dan $303 \mathrm{~mm}$ pada cumi-cumi betina. Daerah distribusi $D$. pealeii yaitu di daerah Samudra Atlantik barat Teluk Meksiko dan Laut Karibia (Vacchione et al., 2008).

Genus Heterololigo (Natsukari, 1984; Vacchione et al., 2008d)

\section{Heterololigo bleekeri}

Heterololigo bleekeri memiliki ciri-ciri mantel sangat panjang dan kecil. Sirip posterior besar, tebal, dengan panjang dua pertiga dari panjang mantel. Tentakel pendek, memiliki cincin penghisap yang kecil terdiri dari 30 gigi tumpul. Heterololigo bleekeri memiliki ukuran sedang sampai besar dengan panjang mantel maksimum $380 \mathrm{~mm}$ pada H. bleekeri jantan dan $301 \mathrm{~mm}$ H. bleekeri betina. Umumnya panjang mantel berkisar antara 200 hingga 250 mm (Okutani et al., 2005). Daerah distribusi $H$. bleekeri terletak di Jepang (Kyusu selatan ke Selat Kuril), perairan Hokkaido, Pantai Korea, Cina Timur 
Laut dan Laut Kuning. Spesies ini dapat ditemukan di perairan dengan kedalaman hingga $150 \mathrm{~m}$ dengan suhu $7-15^{\circ} \mathrm{C}$ (Jereb dan Roper, 2006). Bentuk morfologi dan daerah distribusi H. bleekeri dapat dilihat pada Gambar 10. a

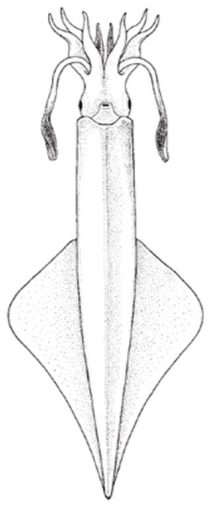

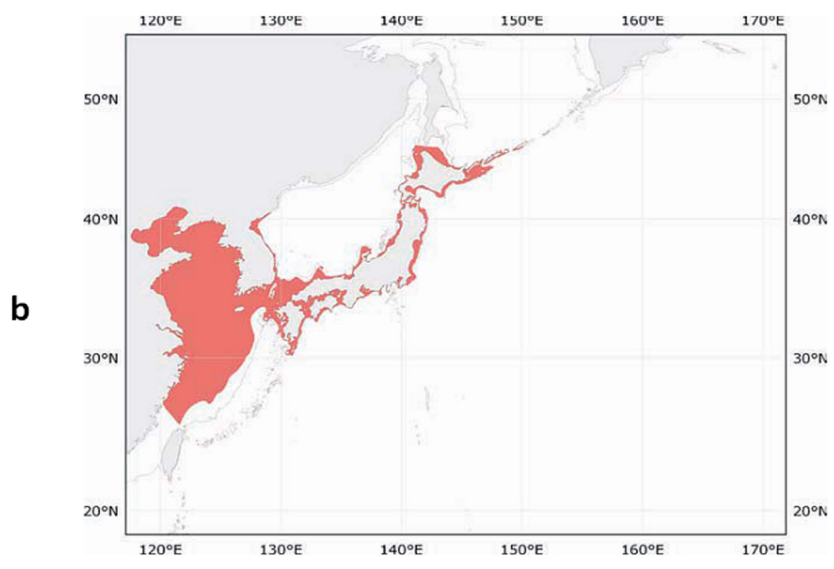

Gambar 10. a) Morfologi dan b) daerah distribusi Heterololigo bleekeri.

\section{Genus Loliolus}

\section{a. Loliolus (Loliolus) hardwickei}

Loliolus hardwickei memiliki ciri-ciri mantel pendek, sirip besar dan berbentuk hati dengan tepi anterior dan lateral membulat. Cincin penghisap terdiri dari 2-7 gigi besar, batang penghisap ventral membesar dan menyatu seluruhnya dengan membran trabeculate ventral. Loliolus hardwickei berukuran kecil dengan panjang mantel maksimum berukuran $88 \mathrm{~mm}$ (Vacchione et al., 2008). Bentuk morfologi $L$. hardwickei dapat dilihat pada Gambar 11. Daerah distribusi L. hardwickei terletak di Samudera Hindia, dari Teluk Persia bagian utara di sepanjang pantai India, Burma (Myanmar), dan di seluruh Indonesia. a

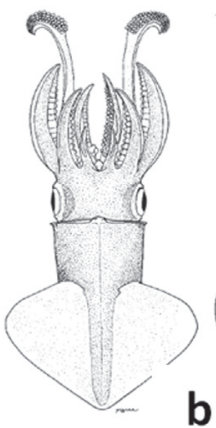

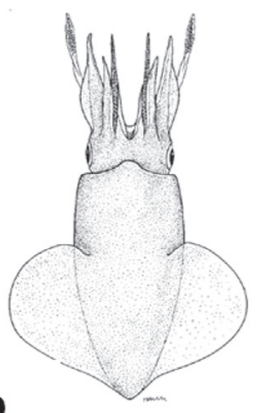

C

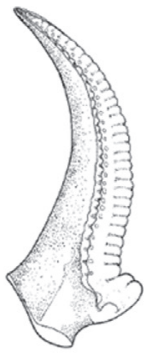

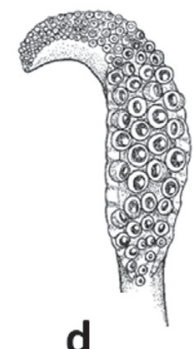

d

Gambar 11. Morfologi Loliolus hardwickei a) jantan, b) betina, c) hectocotylus, d) tentacular. 


\section{b. Loliolus (Loliolus) affinis}

Loliolus affinis memiliki ciriciri sirip besar dan berbentuk hati, kepala lebar dan pendek, mata besar, membran pelindung ventral lebar dan menebal. Tentakel relatif lebih pendek dibandingkan cumi-cumi jenis lain. Loliolus affinis berukuran kecil dengan panjang mantel maksimal $47 \mathrm{~mm}$.
Daerah distribusi cumi-cumi jenis ini yaitu di perairan pesisir wilayah IndoMalayan, dari timur Teluk Benggala ke Laut Andaman, Thailand, Indonesia, dan Kamboja (Okutani et al., 2005). Spesies ini ditemukan di habitat pantai dangkal dengan kedalaman 13-15 m. Ukuran panjang mantel maksimum yaitu $22 \mathrm{~mm}$ pada L. affinis jantan. a

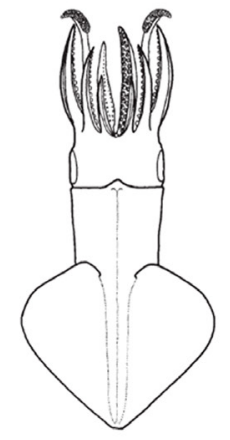

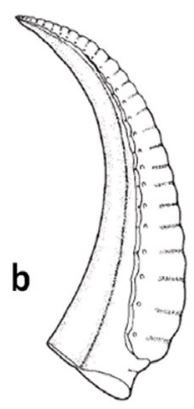

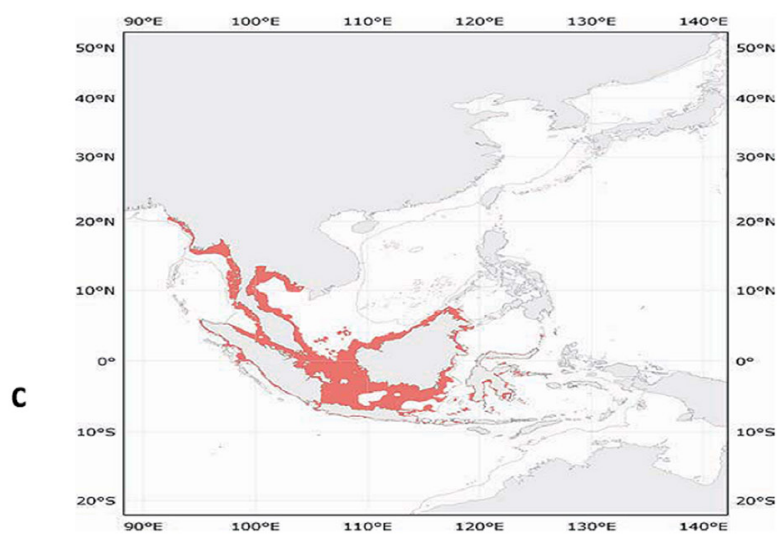

Gambar 12. Morfologi a) dorsal, b) hectocotylus dan c) daerah distribusi L. Affinis.

\section{c. Loliolus (Nipponololigo) beka}

Loliolus beka memiliki ciri-ciri mantel pendek, sirip berbentuk belah ketupat, lebar sirip setengah dari panjang mantel, Lengan hectocotylus pada $L$. beka jantan lebih panjang dari betina. Cincin penghisap dilengkapi dengan 1820 gigi tajam. Loliolus beka berukuran kecil dengan panjang mantel maksimum
$87 \mathrm{~mm}$, ditemukan di perairan pesisir dan muara khususnya teluk. Daerah distribusi cumi-cumi jenis ini terletak di daerah beriklim tropis antara lain Samudra Pasifik barat, sepanjang Asia Tenggara, Perairan pesisir dari Jepang Selatan dan pulau Hainan ke Teluk Thailand dan Laut Andaman (Okutani et al., 2005). Bentuk morfologi dan daerah distribusi Loliolus beka dapat dilihat pada Gambar 13. 

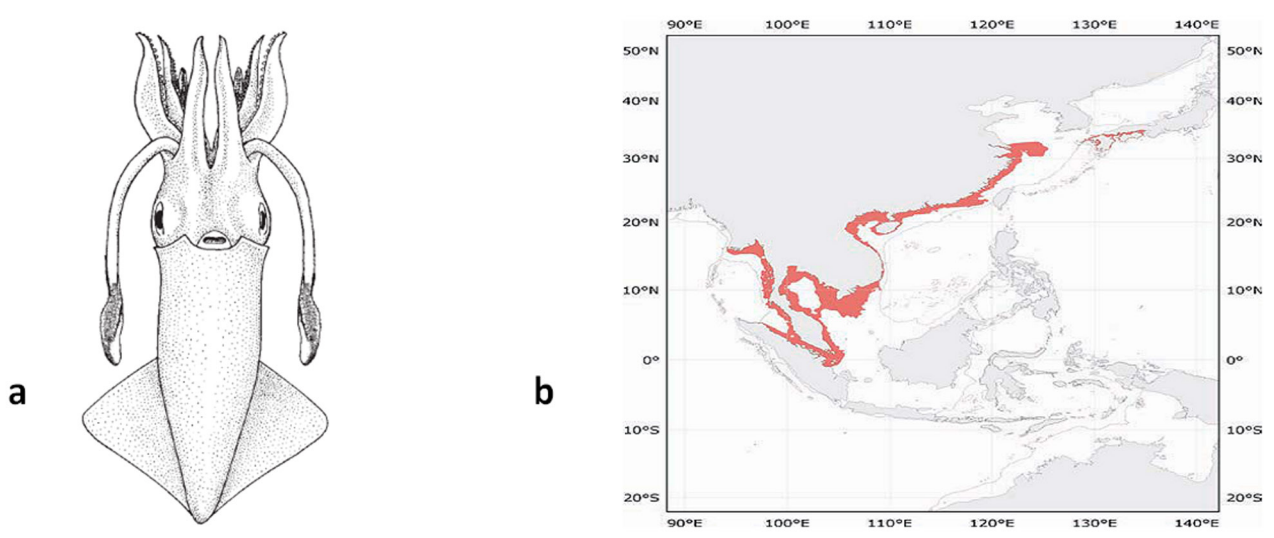

Gambar 13. a) Morfologi dan b) daerah distribusi Loliolus beka (Jereb \& Roper, 2010).

d. Loliolus (Nipponololigo) japonica (Hoyle, 1885 ; Vacchione, 2008e)

Loliolus japonica memliki ciri-ciri mantel berukuran kecil, panjang sirip setengah dari panjang mantel. Panjang mantel L. japonica maksimum 130-150 $\mathrm{mm}$. Daerah distribusi L. japonica di sekitar Samudra Pasifik bagian barat dari Laut Kuning, Timur Laut Cina ke Perairan Vietnam selatan, utara Jepang dan selatan Hokkaido. Pemijahan berlangsung selama musim panas dan gugur di kedalaman antara 1-10 m (Okutani et al., 2005). Bentuk morfologi dan daerah distribusi Loliolus japonica dapat dilihat pada Gambar 14.
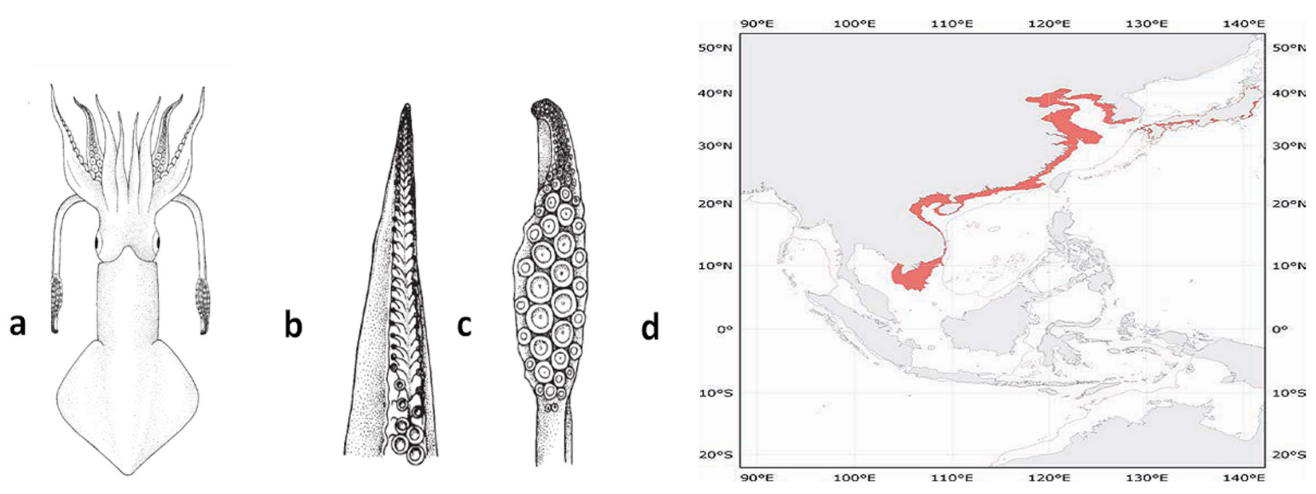

Gambar 14. Morfologi Loliolus japonica a) dorsal, b) hectocotylus, c) tentacular club, d) daerah distribusi (Jereb \& Roper, 2010).

\section{e. Loliolus (Nipponololigo) sumatrensis}

Loliolus sumatrensis memiliki ciriciri mantel pendek, sirip berbentuk belah ketupat. Panjang sirip 65\% dari panjang mantel, kepala kecil dengan mata yang relatif besar. Cincin penghisap terdiri dari 6-15 gigi tajam. Loliolus sumatrensis 
berukuran kecil dengan panjang mantel maksimum $120 \mathrm{~mm}$ (Vecchione et al., 2008e). Daerah distribusi spesies ini yaitu perairan selatan Jepang dan Korea Selatan, Sumatera, Cina, Thailand, Filipina, Indonesia, Teluk Benggala,
Laut Andaman ke pantai timur India dan Kepulauan Maldives (Okutani et al., 2005) Bentuk morfologi dan daerah distribusi Loliolus sumatrensis dapat dilihat pada Gambar 15. a

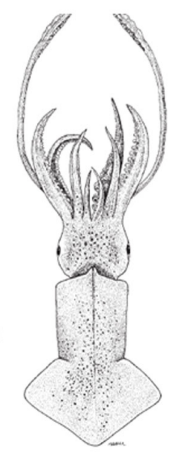

b

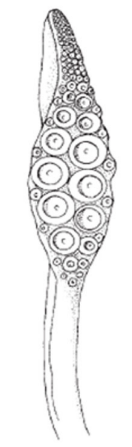

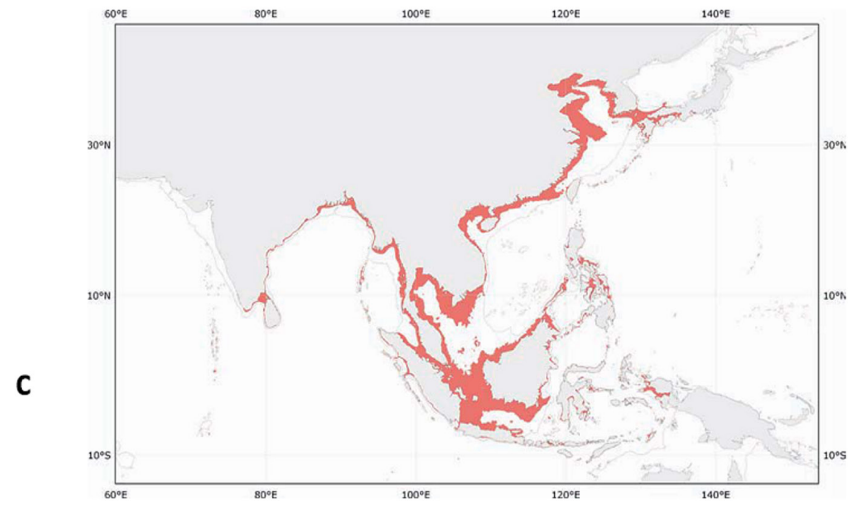

Gambar 15. Morfologi a) ventral, b) tentacular club dan c) daerah distribusi $L$.sumatrensis.

\section{f. Loliolus (Nipponololigo ) uyii}

Loliolus uyii memiliki ciri-ciri mantel pendek dan lebar, panjang sirip $60 \%$ dari panjang mantel. Lengan cincin penghisap terdiri dari 3-6 gigi tajam dengan panjang mantel maksimum 113 $\mathrm{mm}$. Daerah distribusi Loliolus uyii yaitu daerah beriklim tropis Indo-West Pacific Ocean, di barat daya Jepang, Taiwan, Laut Cina Timur dan Selatan. Spesies ini ditemukan di kedalaman $50 \mathrm{~m}$ (Jereb \& Roper, 2010). Bentuk morfologi dan daerah distribusi Loliolus uyii dapat dilihat pada Gambar 16.
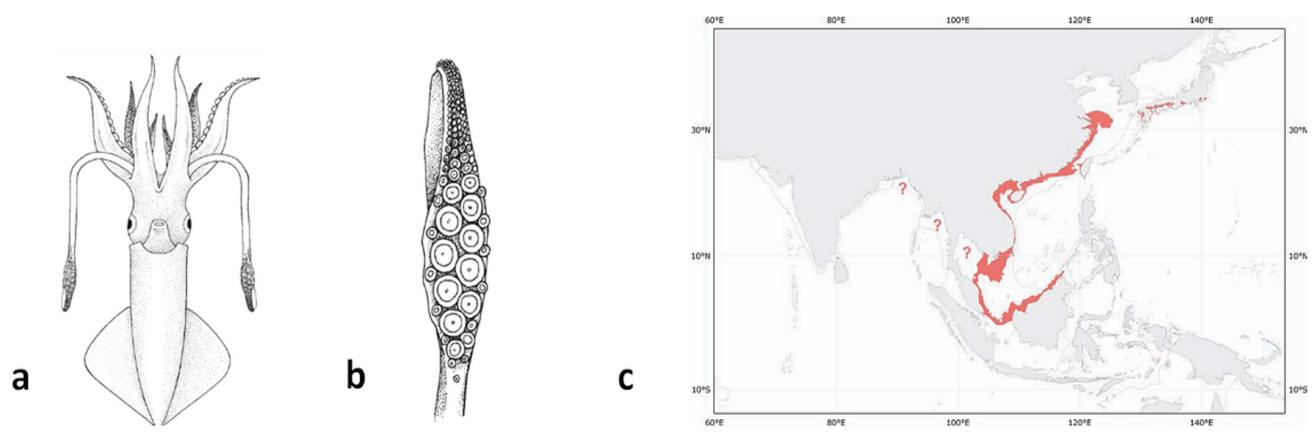

Gambar 16. Morfologi a) ventral, b) tentacular club, c) daerah distribusi Loliolus Uyii. 


\section{PENUTUP}

Famili Lolinginidae memiliki ciri mantel memanjang, ramping, dengan sirip sebagian besar berbentuk belah ketupat, panjang sirip bervariasi dan terdapat pada perairan dengan kedalaman hingga $700 \mathrm{~m}$, bersifat diurnal dan peka terhadap cahaya (fototaksis positif). Famili Lolinginidae diklasifikasikan ke dalam 10 genus, namun hanya dua genus dari Famili Lolinginidae yang tersebar di seluruh Perairan Indonesia yaitu Loliolus dan Uretheuthis.

\section{DAFTAR PUSTAKA}

Adam, W. 1941. Cephalopoda. In: Résultats scientifiques des croisières du Navire-école Belge "Mercator". Volume III. Mémoires du Musée Royal d'Histoire Naturelle de Belgique, series 2, 21: 83-162.

Anderson, F. E., V. Laptikhovsky, A. Pilsits and G. Bello. 2006. Phylogeny and population genetics of Alloteuthis (Loliginidae) and discovery of criptic species. In: Cephalopod Life Cycles. Cephalopod International Advisory Council 2006, Hobart, Tasmania: 34.

Anderson, F. E., A. Pilsits, S. Clutts, V. Laptikhovsky, G. Bello, E. Balguerias, M. Lipinski, C. Nigmatulin, J. M. F. Pereira, U. Piatkowski, J. P. Robin, A. Salman and M. G. Tasende. 2008. Systematics of Alloteuthis (Cephalopoda: Loliginidae) based on molecular and morphometric data. Journal of Experimental Marine Biology and Ecology, 364: 99-109.

Arkhipkin, A. I., V. V Laptikhovsky, A. M. Sirota and R. Grzebielec. 2006. The role of the Falkland Current in the dispersal of the squid Loligo gahi along the Patagonian Shelf. Estuarine, Coastal and Shelf Science, 67 (1-2): 198-204.

Chodrijah, U. dan Budiarti T. W. 2011. Beberapa aspek biologi cumicumi jamak (Loligo duvaucelli) yang didaratkan di Belanakan, Subang - Jawa barat. BAWAL. 3(6) : 357-362

Budiyanto, A. dan H. Sugiarto. 1997. Catatan mengenai si tangan delapan (Gurita/Octopus spp). Oseana. 22(3): $25-33$

Hartati, S. 2004. Panduan Pembelajaran Biologi. Mediatama, Surakarta: 15-30

Hastie, L. C., G. J. Pierce, J. Wang, I. Bruno, A. Moreno, U. Piatkowski and J. P. Robin. 2009. Cephalopods in the north-eastern Atlantic: species, biogeography, ecology, exploitation and conservation. Oceanography and marine biology: an annual review, 47: 111-190.

Jereb, P. M. Vecchione, and C. F. E. Roper. 2010. Family Loliginidae. In P. Jereb and C. F. E. Roper, eds. 
Cephalopods of the world. An annotated and illustrated catalogue of species known to date. Vol 2. Myopsid and Oegopsid Squids. FAO Species Catalogue for Fishery Purposes. $4(2): 38-117$.

Jereb, F. and Roper, C. F. E. 2006. Cephalopods of the Indian Ocean. A review. Part I. Inshore Squids (Loliginidae) collected during the International Indian Ocean Expedition. Journal of Fish. 119(1): 91-136

[KKP]. Kementerian Kelautan dan Perikanan Republik Indonesia. 2013. Statistik Ekspor Perikanan 2013, 2012, dan 2011. Direktorat Jendral Pengolahan dan Pemasaran Hasil Perikanan. http:/ $\underline{w w w}$. kkp.go.id.

[KKP]. Kementerian Kelautan dan Perikanan. 2013. Informasi Cumi-cumi. Direktorat prasarana Perikanan Tangkap. http:/www.kkp.go.id

Lipinski, M. R. 1990. The distribution of cephalopods in South African waters and world-wide. South African Comm. Fishermen, 2: $10-11$.

Nateewathana, A. 1992. Taxonomic studies on Loliginid squids (Cephalopoda: Loliginidae) from the Andaman Sea coast of Thailand. Phuket Marine Biological Centre Research
Bulletin, 57: 1-40.

Natsukari, Y. 1984. Taxonomical and morphological studies on the loliginid squid. V. Re-description of the type specimen of Loligo sumatrensis d'Orbigny, Japanese Journal of Malacology, 43:260-263.

Nontji, A. 2002. Laut Nusantara. Djambatan. Jakarta: 93-110

Okutani, T. 2005. Cuttlefishes and squids of the world. National Cooperative Association of Squid Processors, Tokyo: 253

Perez, J. A. A., D. C. Aguiar de and U.C. Oliveira. 2002. Biology and population dynamics of long-finned squid Loligo plei (Cephalopoda: Loliginidae) in southern Brazilian waters. Fisheries Research, 58: 267279.

Prima, A. P. dan R. Puspasari. 2011. Model Produksi dan Laju Tangkap Kapal Bouke Ami yang Berbasis di PPN Kejawanan, Cirebon Jawa Barat. Pusat Penelitian Pengelolaan dan Konservasi Sumber Daya Ikan. Jakarta.

Roper, C. E. F., M. J. Sweeney and Nauen. 1984. Cephalopods of The Word. An annotated and illustrated catalogue of interest to fisheries. FAO Fisheries Synopsis. 3:112-127

Rodger, R. W. A. 1991. Fish facts an ikkustrated guide to commercial 
species. Van Norstrand Reinhold. New York: 162-163.

Rocha, F. A. Guerra dan A. F. Gonzalez. 2001. A review of reproductive strategies in cephalopods. Biological Review. 76 (1): 291304.

Sheri A. 2016. Squid (Giant) Architeuthis dux. http://www. exploringnture.org. Diakses pada 22 Juli 2018.

Vega, M. A., F. J. Rocha, A. Guerra and C. Osorio. 2002. Morphological differences between the Patagonian squid Loligo gahi populations from the Pacific and Atlantic oceans. Bulletin of Marine Science, 71(2): 903913.

Vecchione, M., E. Shea, S. Bussarawit, F. Anderson, D. Alexeyev, C. C. Lu, T. Okutani, M. Roeleveld, C. Chotiyaputta, C. F. E. Roper, E. Jorgensen and N. Sukramongkol. 2005. Systematics of Indo-West Pacific Loliginids. Phuket Marine Biological Center Research Bulletin. 66(1): 2326.

Vecchione, M. 2008a. Loligo Lamarck, 1798. Inshore squid http:// tolweb.org/Loligo/ In: The Tree of Life Web Project. Diakses pada tanggal 7 Juli 2018.
Vecchione, M. 2008b. Alloteuthis Wulker, 1920. http://tolweb. org/Alloteuthis/. In: The Tree of Life Web Project. Diakses pada tanggal 7 Juli 2018.

Vecchione, M. 2008c. Doryteuthis Naef, 1912. http://tolweb.org/ Doryteuthis/ in:The Tree of Life Web Project. Diakses pada tanggal 7 Juli 2018

Vecchione, M. 2008d. Heterololigo Natsukari, 1984. Heterololigo bleekeri (Keferstein, 1866). http://tolweb.org/Jeterp;p;ogp bleekeri/. In: The Tree of Life Web Project. Diakses pada tanggal 7 Juli 2018

Vecchione, M. 2008e. Loliolus Steenstrup, 1856. Version 04 March 2008 (under construction). $\underline{\mathrm{http}: / /}$ tolweb.org/Loliolus/. In: The Tree of Life Web Project. Diakses pada tanggal 7 Juli 2018

Zeidberg, L. D., W. M. Hamner, N. P. Nezlin and A. Henry. 2006. The fishery for California market squid (Loligo opalescens) (Cephalopoda: Myopsida). Fishery Bulletin, 104: 46-59 